Article

\title{
Effect of Sludge Amendment on Remediation of Metal Contaminated Soils
}

\author{
Andrés Navarro \\ Department of Fluid Mechanics, Polytechnic University of Catalonia (UPC), Colón, 7, 08222 Terrassa, \\ Barcelona, Spain; E-Mail: navarro@mf.upc.edu; Tel.: +34-93-739-8151; Fax: +34-93-739-8101
}

Received: 24 October 2012; in revised form: 16 November 2012 / Accepted: 20 November 2012 /

Published: 28 November 2012

\begin{abstract}
Column-leaching and pilot-scale experiments were conducted to evaluate the use of biosolids (sewage sludges) to control the mobilization of metals from contaminated soils with smelting slags. The pilot-scale experiments using amended soils showed that $\mathrm{Cu}$, $\mathrm{Pb}$ and $\mathrm{Sb}$ were retained, decreasing their concentrations from $250 \mu \mathrm{g} / \mathrm{L}, 80 \mu \mathrm{g} / \mathrm{L}$ and $6 \mu \mathrm{g} / \mathrm{L}$, respectively in the leachates of contaminated soils, to $<20 \mu \mathrm{g} / \mathrm{L}, 40 \mu \mathrm{g} / \mathrm{L}$ and $4 \mu \mathrm{g} / \mathrm{L}$, respectively, in the amended material. Hydrogeochemical modeling of the leachates using Minteq revealed that the degree of complexation of $\mathrm{Cu}$ rose $56.3 \%$ and $57.6 \%$ in leachates of amended soils. Moreover, $\mathrm{Cu}$ may be immobilized by biosolids, possibly via adsorption by oxyhydroxides of Fe or sorption by organic matter. The partial retention of $\mathrm{Pb}$ coincides with the possible precipitation of chloropyromorphite, which is the most stable mineral phase in the $\mathrm{pH}$-Eh conditions of the leachates from the amended material. The retention of $\mathrm{Sb}$ may be associated with the precipitation of $\mathrm{Sb}_{2} \mathrm{O}_{3}$, which is the most stable mineral phase in the experimental conditions. The organic amendments used in this study increased some metal and metalloid concentrations in the leachates (Fe, $\mathrm{Mn}, \mathrm{Ni}$, As and $\mathrm{Se}$ ), which suggests that the organic amendments could be used with caution to remediate metal contaminated areas.
\end{abstract}

Keywords: contaminated soil; leachates; biosolids; metals

\section{Introduction}

Soils contaminated with smelting wastes have traditionally been considered poor reactive materials because the potential contaminants are encapsulated in low-solubility compounds such as silicates, 
oxides and glassy forms [1,2]. However, smelter slags are reactive and may be the source of metals such as $\mathrm{Ag}, \mathrm{As}, \mathrm{Ba}, \mathrm{Cd}, \mathrm{Cu}, \mathrm{Pb}, \mathrm{Sb}$ and $\mathrm{Zn}$ in stream, soil and groundwater contamination [3-12].

Thus, base-metal slag deposits at the Penn Mine in California contained relatively high concentrations of $\mathrm{As}, \mathrm{Ba}, \mathrm{Cd}, \mathrm{Cu}, \mathrm{Pb}$ and $\mathrm{Zn}$, which were hosted by different types of phases [13]. Geochemical modeling of field and laboratory data indicated that the main processes controlling dissolved metal concentrations were dissolution of fayalite, willemite and glass, sulfide oxidation, and secondary phases, which suggests that the dissolved concentrations of $\mathrm{Al}, \mathrm{Ba}, \mathrm{Cu}, \mathrm{Mn}, \mathrm{SiO}_{2}$, and $\mathrm{SO}_{4}$ may be controlled by mineral solubilities. Also, secondary minerals appeared as coatings on surfaces and as precipitates of amorphous $\mathrm{Fe}, \mathrm{Al}$ oxyhydroxides, chalcanthite, siderotil, jarosite, brochantite and gypsum [7] and may control the mobility of metals to soil and water bodies.

The use of organic amendments as reactive materials may control metal mobilization $[14,15]$ and aid the reclamation of contaminated soils at smelting sites, since such areas typically lack natural vegetation and have other deficiencies [16]. In addition, reactive layers containing labile organic carbon may promote bacterially mediated sulfate reduction reactions and the removal of sulfate and dissolved metals from contaminated acid mine drainages [17]. Organic amendments from municipal solid waste compost have been used in the reclamation of mine spoils from limestone quarries [18]. In addition, sugar foam waste has been applied to red soils [19] in a semiarid environment similar to the study area conditions.

Basta et al. [20] showed the effectiveness of lime-stabilized biosolids at reducing the extractability and bioavailability of $\mathrm{Cd}, \mathrm{Pb}$ and $\mathrm{Zn}$ from smelter-contaminated soils, and indicated that alkaline organic treatments reduced metal extractability and phytoavailability.

The use of sewage sludge on sulfide mine tailings is based on supplying nutrients to promote plant growth [21,22] and thus increasing biomass production [23]. The availability of metals after the application of sludge to tailings deposits has also been observed [24]. Some studies showed an increase in sulfide oxidation or reductive dissolution reactions in mine waste $[25,26]$ and the release of metals. In addition, the application of polylactic acid amendments to smelter tailings increased the bioavailability of $\mathrm{Pb}, \mathrm{Ni}$ and $\mathrm{Zn}$ [27]. The use of manure compost and sewage sludge on $\mathrm{Pb} / \mathrm{Zn}$ tailings led to a decrease in $\mathrm{pH}$, an increase in electrical conductivity (EC) and in extractable $\mathrm{Cu}$, and a decrease in extractable $\mathrm{Pb}$ and $\mathrm{Zn}$ [28]. Ni mobilization due to the formation of organic complexes from sewage sludge may be environmentally significant because of the relatively poor retention of $\mathrm{Ni}$ by the sludge [29]. The use of column experiments and the application of organic amendments such as cattle manure on mine tailings have also shown the mobilization of heavy metals $(\mathrm{Zn}, \mathrm{Cd}, \mathrm{Pb})$ by the leaching of $\mathrm{Pb}-\mathrm{Zn}$ mine waste [16].

Laboratory studies in which biosolids were applied to $\mathrm{Pb}-\mathrm{Ag}$ mine tailings showed that $\mathrm{Fe}, \mathrm{Mn}, \mathrm{Zn}$ and $\mathrm{Pb}$ were removed and $\mathrm{Cu}$ and $\mathrm{Ni}$ mobilized. Experiments carried out on $\mathrm{Pb}-\mathrm{Fe}$ tailings produced similar results, in which $\mathrm{Cu}, \mathrm{Pb}, \mathrm{Fe}$ and $\mathrm{Mn}$ were retained and $\mathrm{Ni}$ and $\mathrm{Zn}$ mobilized [15]. In addition, composted sludge has been shown to have a high affinity for metals such as $\mathrm{Pb}$ [30]. Furthermore, Park et al. [31] showed that low metal organic amendments could be used as a sink for reducing the bioavaibility of metals in contaminated soils. In one current treatment technique, an organic carbon reactive material is used to stimulate sulfate reduction and the subsequent metal sulfide precipitation [32].

The reduction of sulfates by organic carbon may take the following form:

$$
2 \mathrm{CH}_{2} \mathrm{O}+\mathrm{SO}_{4}{ }^{2-} \Rightarrow 2 \mathrm{HCO}_{3}^{-}+\mathrm{H}_{2} \mathrm{~S}
$$


The $\mathrm{H}_{2} \mathrm{~S}$ that is generated, the $\mathrm{Fe}$ (II) and other metallic species such as $\mathrm{As}, \mathrm{Cd}, \mathrm{Co}, \mathrm{Cu}, \mathrm{Ni}, \mathrm{Pb}$ and $\mathrm{Zn}$ may precipitate, thereby producing sulfide minerals:

$$
\mathrm{Fe}^{2+}+\mathrm{H}_{2} \mathrm{~S}=\mathrm{FeS}(\mathrm{s})+2 \mathrm{H}^{+}
$$

The main objectives of this study were to evaluate how organic amendments affect metal mobility from contaminated soils with smelter slags and evaluate the possible remediation of extensive contaminated areas, which are the source of metal mobilization.

\section{Materials and Methods}

\subsection{Research Site}

The area comprising the Sierra Almagrera (Figure 1), located $90 \mathrm{~km} \mathrm{NE}$ of the city of Almería (SE Spain), together with the Iberian Pyrite Belt and the Cartagena mining district, is the oldest metallurgical and mining area in the Iberian Peninsula [33-35]. During the nineteenth century and the early twentieth century, the smelting plants located along the Mediterranean coastline of the Sierra Almagrera district produced approximately 550,000 t of $\mathrm{Pb}$ and $3000 \mathrm{t}$ of Ag. The Sierra Almagrera area is located in a semi-arid region that is characterized by a highly irregular hydrological regime with long dry periods and intermittent periods of rainfall, in which the volume of precipitation in a few hours can exceed the annual average. The study area is close to the shoreline in the coastal part of the Sierra Almagrera, where the main slag dumps were generated between 1850 and 1885 (Figure 1). The waste deposits are now covered by anthropogenic soils and industrial facilities built over part of the metallurgical slags, which were partially used in the road construction. The site covers an area of approximately $120,000 \mathrm{~m}^{2}$ and has a simple geological structure that comprises a metamorphic basement (phyllites and schists), a level of weathered phyllites, layers of smelter slags, and topsoil mixed with other waste. The study area, which is now used for industrial activities, contains a 4-5 m deep unconfined aquifer. The $2 \mathrm{~m}$ deep saturated zone is related to levels established by old smelter slags and/or colluvial deposits.

An important environmental concern related with these contaminated areas is associated with the damage of Posidonia Oceanica prairies in the coastal area [36], and the presence of significative contents of metals in the superficial marine sediments. Since Posidonia Oceanica is a seagrass endemic to Mediterranean Sea and is protected by the European laws, the conservation of this seagrass and, therefore, the control of metal contamination in the terrestrial source-areas may be of environmental concern in the old mining areas of SE Spain. The detailed characterization of the slags dumped in this area was described by Navarro et al. [9]. 
Figure 1. (a) Location of the study area and regional Geology. NQ: Neogene and Quaternay; UM: Volcanic-shoshonitic rocks of Miocene age; PT: Metamorphic basement; F: Main fractures. (b) Detail of smelting slags dumps in Sierra Almagrera (Almería, Spain). (c) Detail of the experimental device.

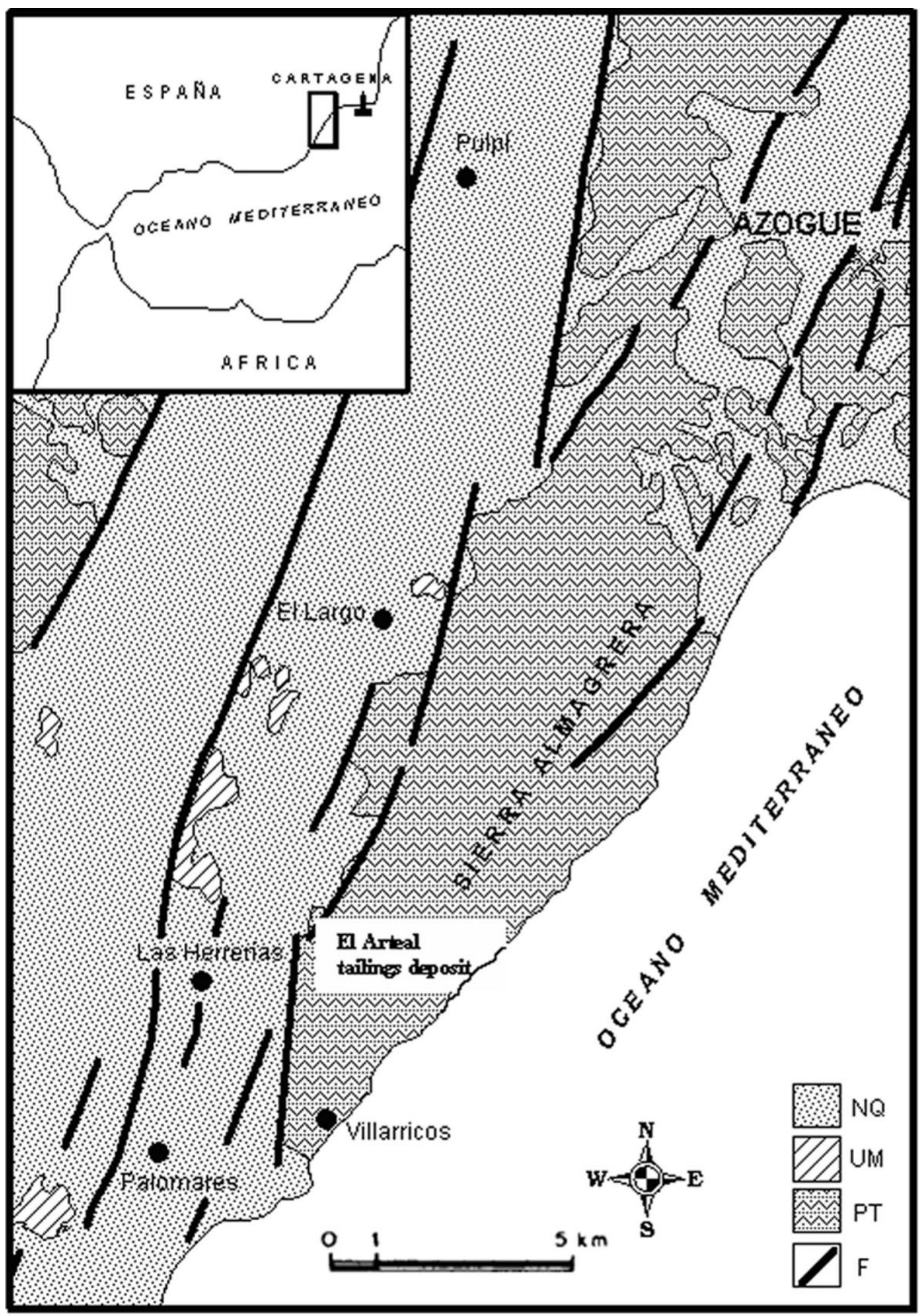

(a) 
Figure 1. Cont.

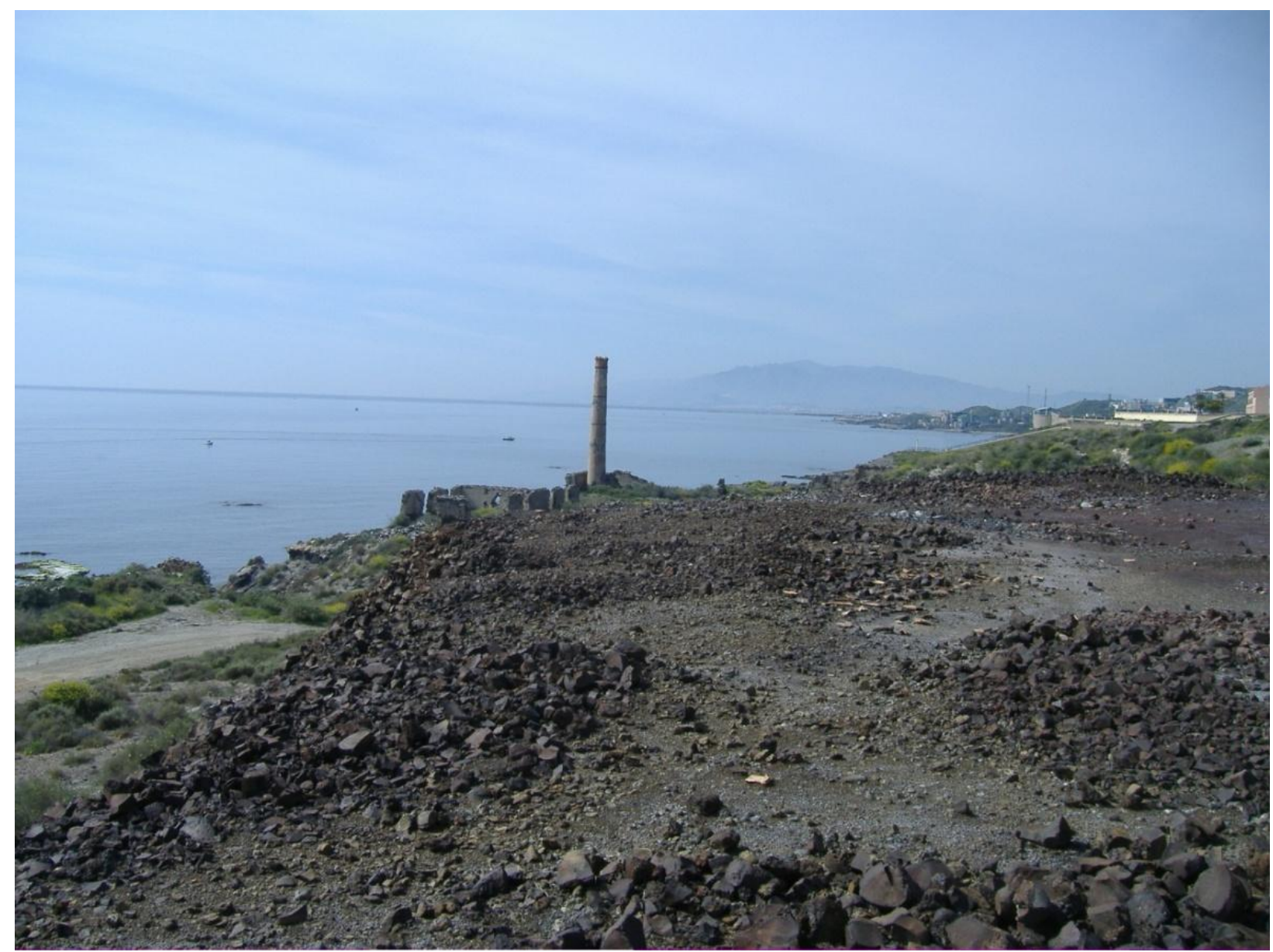

(b)

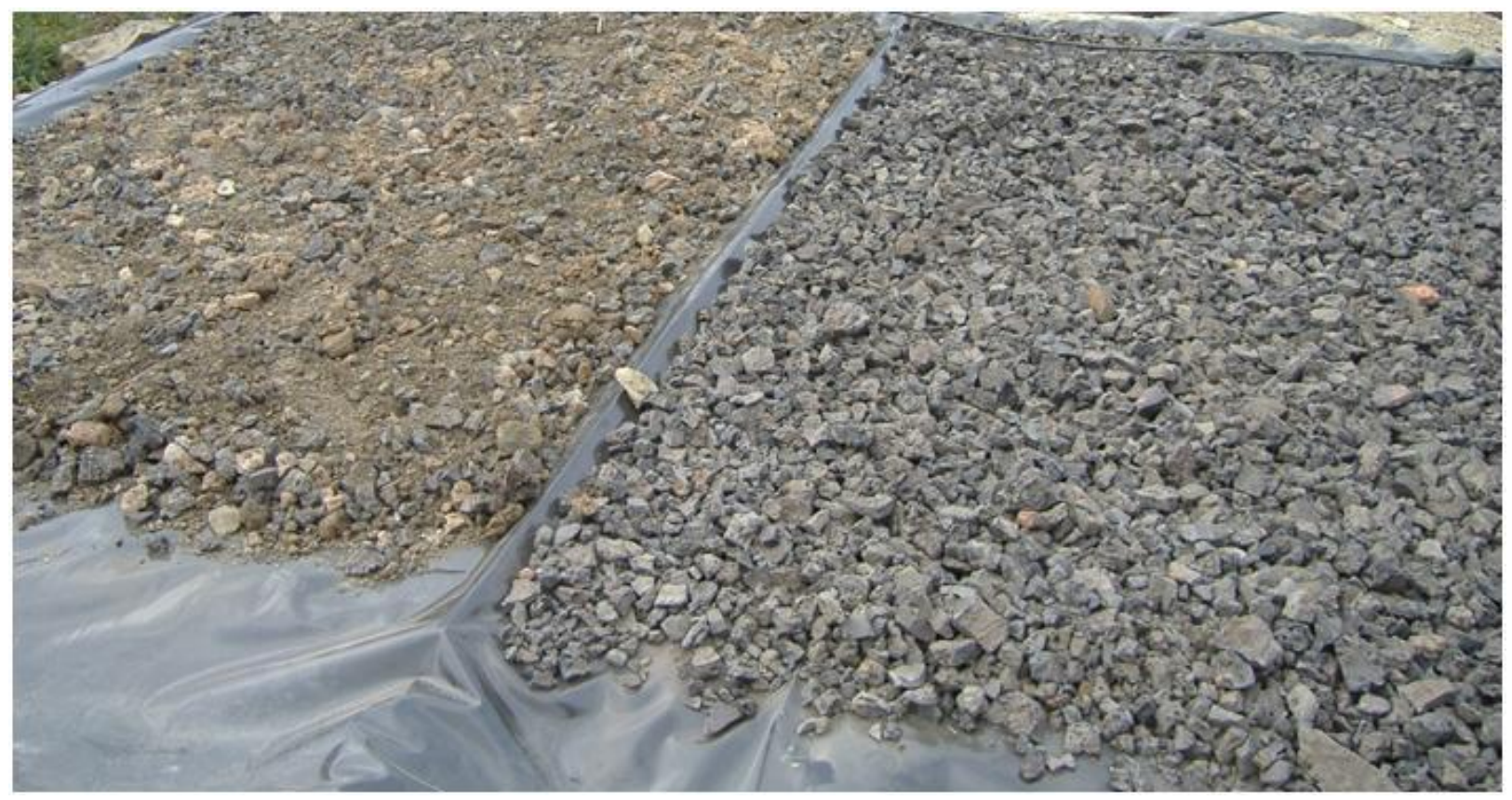

(c) 


\subsection{Organic Amendments}

The sewage sludge used is a stabilized biosolid from a depuration process in which seawater was used to eliminate organic matter from pharmaceutical waste waters. The sewage sludge showed a grain size distribution that was dominated by fine particles $(94 \%-98 \%)$, an elevated content of organic matter (6.2\%-13\%) and a high content of soluble salts and gypsum (Table 1). Other physical parameters of the biosolid were a low dry density and a high degree of saturation.

In addition, the mechanical properties of sewage sludge were determined from soil laboratory tests. Thus, Atterberg limits were calculated showing a liquid limit of 60.8-65.4, a plastic limit of 59.1-60.0 and a plasticity index of 0.8-6.2 (Table 1). Besides, the air-dried compacted sludge was tested in vane shear assays, showing an effective angle of shearing resistance of 29.2-30.3, below the values obtained in similar experiences [37]. The sewage sludge had a high content of $\mathrm{Ca}(17.7 \%), \mathrm{S}(5.28 \%), \mathrm{Mg}(0.74 \%)$, $\mathrm{P}(5.71 \%)$ and particularly $\mathrm{Na}(1.38 \%)$, possibly due to the use of seawater in the treatment process that created the sludge. The metal content in the sludge was very low (Table 2), except for $\mathrm{V}(142 \mathrm{mg} / \mathrm{kg})$. The amounts of As $(9.9 \mathrm{mg} / \mathrm{kg}), \mathrm{Cd}(0.5 \mathrm{mg} / \mathrm{kg}), \mathrm{Cu}(12 \mathrm{mg} / \mathrm{kg}), \mathrm{Fe}(7900 \mathrm{mg} / \mathrm{kg}), \mathrm{Pb}(7 \mathrm{mg} / \mathrm{kg})$ and $\mathrm{Zn}$ $(78 \mathrm{mg} / \mathrm{kg}$ ) were close to the concentrations detected in non-contaminated soils in the nearby region (Table 2). However, concentrations of $\mathrm{Ba}$ and $\mathrm{Ni}$ are above the values detected in the non-contaminated soils. The metal content of the sludge did not exceed the limits imposed by Spanish environmental regulations (RD 13-10/1990) for the total metal content in sewage sludge used on agricultural land and are above the Netherlands Soil Contamination Guidelines (intervention values).

\subsection{Contaminated Soils and Smelting Slags}

The total amount of metals and trace elements was analyzed by Instrumental Neutron Activation Analysis (INAA) and Inductively Coupled Plasma Optical Emission Spectroscopy (ICP-OES). Au, $\mathrm{Ag}, \mathrm{As}, \mathrm{Ba}, \mathrm{Br}, \mathrm{Ca}, \mathrm{Ce}, \mathrm{Co}, \mathrm{Cr}, \mathrm{Cs}$, Eu, Fe, Hf, Hg, Ir, La, Lu, Na, Ni, Nd, Rb, Sb, Sc, Se, Sm, Sn, Sr, $\mathrm{Ta}$, Th, Tb, U, W, Y and $\mathrm{Yb}$ were found by INAA, and $\mathrm{Mo}, \mathrm{Cu}, \mathrm{Pb}, \mathrm{Zn}, \mathrm{Ag}, \mathrm{Ni}, \mathrm{Mn}, \mathrm{Sr}, \mathrm{Cd}, \mathrm{Bi}, \mathrm{V}, \mathrm{Ca}$, $\mathrm{P}, \mathrm{Mg}, \mathrm{Tl}, \mathrm{Al}, \mathrm{K}, \mathrm{Y}$ and Be were found by ICP-OES.

Previously, the mineralogy of soils and some slags was examined under a binocular microscope and analyzed using X-ray powder diffraction (XRD) at Actlabs (Ontario, Canada) and the Autonomous University of Barcelona (UAB).

Contaminated soils and smelting slags used in the leaching experiments showed high concentrations of $\mathrm{Ag}(46.1 \mathrm{mg} / \mathrm{kg}), \mathrm{As}(51.6 \mathrm{mg} / \mathrm{kg}), \mathrm{Ba}(101,000 \mathrm{mg} / \mathrm{kg}), \mathrm{Cu}$ (227 mg/kg), $\mathrm{Fe}$ (20.4\%), $\mathrm{Mn}(10,600 \mathrm{mg} / \mathrm{kg}), \mathrm{Pb}(4900 \mathrm{mg} / \mathrm{kg}), \mathrm{Sb}(243 \mathrm{mg} / \mathrm{kg})$ and $\mathrm{Zn}(5070 \mathrm{mg} / \mathrm{kg})$ (Table 2).

The slags were composed mainly of quartz, fayalite, barite, orthoclase and $\mathrm{Zn}-\mathrm{Pb}-\mathrm{Fe}$ alloys. In addition, the following weathering-related secondary phases were detected: jarosite-natrojarosite, corrensite, ferrihydrite, kastningite and wuestite. No significant glass phases were detected in previous analyzed slags [9]. In addition, previous hydrogeochemical data showed that groundwater in the area had been contaminated by $\mathrm{Cu}, \mathrm{Fe}, \mathrm{Mn}, \mathrm{Pb}, \mathrm{Zn}$ and As to maximum concentrations of $0.64 \mathrm{mg} / \mathrm{L} \mathrm{Cu}$, $40 \mathrm{mg} / \mathrm{L} \mathrm{Fe}, 0.6 \mathrm{mg} / \mathrm{L} \mathrm{Mn}, 7.6 \mathrm{mg} / \mathrm{L} \mathrm{Zn}, 5.1 \mathrm{mg} / \mathrm{L} \mathrm{Pb}$ and $0.019 \mathrm{mg} / \mathrm{L} \mathrm{As} \mathrm{[9].} \mathrm{Differences} \mathrm{in} \mathrm{the}$ geochemical composition between the historically analyzed slags [9] and the slags used in the experiments may reflect the variation in furnace charges and smelting conditions over time [6]. 
Table 1. Main characteristics of biosolid (sewage sludge) used in the experiments.

\begin{tabular}{|c|c|c|c|c|c|c|c|c|c|c|c|c|c|c|c|}
\hline Sample & $\begin{array}{c}\text { Gravel } \\
(\%)\end{array}$ & $\begin{array}{c}\text { Sand } \\
(\%)\end{array}$ & $\begin{array}{c}\text { Fine Sand } \\
(\%)\end{array}$ & Fines $(\%)$ & $\begin{array}{c}\text { Organic } \\
\text { Matter (\%) }\end{array}$ & $\begin{array}{c}\text { Soluble } \\
\text { Salts (\%) }\end{array}$ & $\begin{array}{c}\text { Gypsum } \\
(\%)\end{array}$ & $\mathrm{W}(\%)$ & $\rho_{\mathrm{s}}$ & $\rho_{p}$ & $\mathbf{e}_{0}$ & $(\%)$ & $\mathbf{W}_{\mathbf{L}}$ & $\mathbf{W}_{\mathbf{P}}$ & $\mathbf{I}_{\mathbf{P}}$ \\
\hline M0 & 0 & 0 & 2 & 98 & 13 & 29.55 & 32.78 & 112.5 & 0.61 & 2.3 & 2.78 & 93.0 & 60.8 & 60.0 & 0.8 \\
\hline M02 & 0 & 0 & 6 & 94 & 6.2 & $24.7 *$ & - & 41.67 & 1.09 & 2.41 & - & - & 65.4 & 59.1 & 6.2 \\
\hline
\end{tabular}

Gravel: $d_{e}>5 \mathrm{~mm}$; Sand: $d_{e}>2 \mathrm{~mm}$; Fine sand: $d_{e}>0.08 \mathrm{~mm}$; Fines: $d_{e}<0.08 \mathrm{~mm}$; W: biosolid wetness; $\rho_{\mathrm{s}}$ : dry density $\left(\mathrm{g} / \mathrm{cm}^{3}\right)$; $\rho_{\mathrm{p}}$ : particle density $\left(\mathrm{g} / \mathrm{cm}^{3}\right)$; $\mathrm{e}_{0}$ : void ratio; $\mathrm{S}$ : degree of saturation; *: including gypsum; $\mathrm{W}_{\mathrm{L}}$ : liquid limit; $\mathrm{W}_{\mathrm{P}}$ : plastic limit; Ip: plasticity index.

Table 2. Geochemical composition of biosolid, and contaminated materials (contaminated soils P1 to P4 and smelting slags) used in the leaching experiments. Values in $\mathrm{mg} / \mathrm{kg}$, except $\mathrm{Au}(\mathrm{ppb})$ and $\mathrm{Fe}(\%)$.

\begin{tabular}{|c|c|c|c|c|c|c|c|c|c|c|c|c|c|c|c|c|c|c|}
\hline Material & $\mathbf{A u}$ & Ag & $\mathbf{C u}$ & Cd & Mo & $\mathbf{P b}$ & $\mathrm{Ni}$ & $\mathbf{Z n}$ & As & $\mathbf{B a}$ & Co & $\mathrm{Cr}$ & $\mathbf{F e}$ & $\mathrm{Hg}$ & Mn & $\mathbf{S b}$ & Se & $\mathbf{V}$ \\
\hline Biosolid & $<2$ & 0.3 & 12 & 0.5 & 2 & 7 & 39 & 78 & 9.9 & 540 & 3 & 40 & 0.79 & $<1$ & 62 & 2.8 & $<3$ & 142 \\
\hline P1-A & $<2$ & $<0.3$ & 20 & 1.9 & $<1$ & 97 & 57 & 227 & 34.9 & 900 & 18 & 139 & 6.29 & $<1$ & 489 & 4.7 & $<3$ & 142 \\
\hline P1-B & $<2$ & $<0.3$ & 20 & 1.8 & $<1$ & 508 & 43 & 122 & 87.1 & 660 & 19 & 102 & 4.97 & $<1$ & 417 & 16.5 & $<3$ & 64 \\
\hline P2-A & $<2$ & 0.4 & 22 & 12 & 1 & 2450 & 33 & 157 & 278 & 850 & 10 & 100 & 3.93 & $<1$ & 358 & 40.8 & $<3$ & 110 \\
\hline P2-B & $<2$ & 0.6 & 23 & 8.8 & $<1$ & 2390 & 28 & 110 & 324 & 580 & 10 & 88 & 3.63 & $<1$ & 358 & 47.3 & $<3$ & 102 \\
\hline P3-A & $<2$ & 0.6 & 27 & 7.6 & 2 & 4900 & 39 & 192 & 337 & 1030 & 15 & 105 & 4.39 & $<1$ & 469 & 63.4 & $<3$ & 129 \\
\hline 3-B & $<2$ & $<0.3$ & 33 & 8.5 & $<1$ & 2440 & 49 & 229 & 367 & 690 & 18 & 126 & 5.19 & $<1$ & 457 & 34.2 & $<3$ & 162 \\
\hline P4-A & $<2$ & $<0.3$ & 30 & 0.6 & $<1$ & 73 & 41 & 112 & 31.3 & 690 & 13 & 82 & 3.45 & $<1$ & 571 & 4.9 & $<3$ & 107 \\
\hline P4-B & $<2$ & $<0.3$ & 34 & 1.4 & $<1$ & 67 & 52 & 125 & 60.5 & 530 & 16 & 117 & 5.18 & $<1$ & 513 & 7.8 & $<3$ & 142 \\
\hline $\begin{array}{c}\text { Smelting } \\
\text { slags }\end{array}$ & $<2$ & 46.1 & 227 & 0.6 & 18 & 4460 & 17 & 5070 & 51.6 & $10.1 *$ & 10 & 40 & 20.4 & $<1$ & $1.0^{*}$ & 243 & $<3$ & 87 \\
\hline NCS & 3 & $<0.4$ & 15 & $<0.5$ & $<1$ & 17 & 26 & 57 & 16 & 310 & 8 & 55 & 2.69 & $<1$ & 136 & 1.8 & $<3$ & 96 \\
\hline NSGS & -- & -- & 190 & 12 & 200 & 530 & 210 & 720 & 55 & 625 & 240 & 380 & -- & 10 & -- & 15 & -- & -- \\
\hline
\end{tabular}

NCS: non contaminated soils developed over metamorphic materials in the nearby area; NSGS: Netherlands Soil Contamination Guidelines (intervention values); *: \%. 


\subsection{Column Leaching Experiments}

A leaching experiment was conducted in order to characterize the behavior of biosolid and the mobility of their components. The experiment comprised a column test consisted of a water reservoir, a peristaltic pump, a methacrylate column, and a series of instruments for determining some parameters of the effluents in situ, such as $\mathrm{pH}$, Eh, EC (electrical conductivity), temperature and dissolved $\mathrm{O}_{2}$. The column was made in a methacrylate cylinder, thus allowing for visual examination of the progress of the wetting front and detection of preferential flow channels along the column walls. The column was $750 \mathrm{~mm}$ long, with an outer diameter of $150 \mathrm{~mm}$ and a thickness of $5 \mathrm{~mm}[15,38]$.

Low mineralized water (LMW) entered the column through an injection system connected to a metering pump, which emitted a maximum flow of $10 \mathrm{~L} \cdot \mathrm{h}^{-1}$. The chemical characteristics of LMW are shown in Table 3. A constant-head reservoir was used to deliver influent water at a flow rate of $2.4 \mathrm{~L} \cdot \mathrm{h}^{-1}$. The inflow fluid was low mineralization water, which approximates the behavior of rainwater when it comes into contact with the waste in environmental conditions (Table 3). The samples were collected at the bottom of the column as a function of time. The first sample, which corresponds to time 0 , was taken when water started to flow from the lower part of the column. The flow, $\mathrm{pH}$ and EC (electrical conductivity) were measured immediately after the sample was collected. The number of pore volumes reached in the column experiments is given by the following expression:

$$
T_{\mathrm{a}}=V \cdot t \cdot L^{-1}
$$

where $T_{\mathrm{a}}$ is the number of pore volumes, $V$ the pore velocity, $L$ the column length and $t$ the leaching time. In the column experiment, the final $T_{\mathrm{a}}$ was 4.7 pore volumes, which indicates a time period that can be considered as representative.

Table 3. Chemical composition of fluids from column leaching experiment with biosolid. Values in $\mu \mathrm{g} / \mathrm{L}$.

\begin{tabular}{cccccccccccc}
\hline Samples & $\mathbf{P V}$ & $\mathbf{C u}$ & $\mathbf{P b}$ & $\mathbf{S b}$ & $\mathbf{A s}$ & $\mathbf{S e}$ & $\mathbf{M n}$ & $\mathbf{N i}$ & $\begin{array}{c}\mathbf{E C} \\
(\boldsymbol{\mu S} / \mathbf{c m})\end{array}$ & $\begin{array}{c}\mathbf{C l} \\
(\mathbf{m g} / \mathbf{L})\end{array}$ & $\begin{array}{c}\mathbf{S O}_{4} \\
(\mathbf{m g} / \mathbf{L})\end{array}$ \\
\hline SL-1 & 0 & 178 & $<0.1$ & 0.59 & 28.1 & $<0.2$ & 274 & 161 & 5860 & 570 & 980 \\
SL-2 & 0.45 & 13 & 134 & 0.25 & 5.59 & 1.3 & 9.8 & 14 & - & - & - \\
SL-3 & 0.9 & 9.3 & $<0.1$ & 0.21 & 5.31 & 0.5 & 5.4 & 5.5 & - & - & - \\
SL-4 & 1.35 & 4.8 & $<0.1$ & 0.23 & 4.09 & $<0.2$ & 7.9 & 2.2 & - & - & - \\
SL-5 & 1.8 & 9.6 & $<0.1$ & 0.19 & 4.21 & $<0.2$ & 3.3 & 1.8 & - & - & - \\
SL-6 & 2.2 & 2.7 & $<0.1$ & 0.16 & 3.17 & $<0.2$ & 2.4 & 1.9 & - & - & - \\
SL-7 & 2.7 & 1.6 & $<0.1$ & 0.16 & 2.5 & $<0.2$ & 1.4 & 0.5 & - & - & - \\
SL-8 & 3.4 & 2.4 & $<0.1$ & 0.13 & 2.2 & $<0.2$ & 2.8 & 0.7 & - & - & - \\
SL-9 & 4.0 & 1.5 & $<0.1$ & 0.11 & 2.02 & $<0.2$ & 1.1 & 0.4 & - & - & - \\
SL-10 & 4.7 & 6.5 & $<0.1$ & 0.12 & 1.89 & $<0.2$ & 1.5 & 0.4 & - & - & - \\
\hline LMW & - & $<0.2$ & 0.1 & 0.02 & 0.34 & $<0.2$ & $<0.1$ & $<0.3$ & 250 & 5.6 & 11.1 \\
\hline
\end{tabular}

SL: sewage sludge leachates; LMW: low mineralized water used in the column leaching tests; PV: number of pore volumes. 


\subsection{Pilot-Scale Experiments}

The experimental device covered a surface of $30 \mathrm{~m}^{2}$ approximately, divided into two sub-areas of $15 \mathrm{~m}^{2}$ : an area of not-amended materials leaching, and an area of leaching of contaminated materials and organic amendments. These amendments comprised about $10 \%$ by weight of total soil and slags used in the experiment. The experimental system was fed by low mineralized water (LMW) (Tables 4 and 5) for $24 \mathrm{~h}$ with a constant flow rate of $5 \mathrm{~L} \cdot \mathrm{h}^{-1}$. The materials were laid over a low hydraulic conductivity liner (HDEP) with a slope of approximately $5 \%$, to facilitate the leachate movement.

The LMW was introduced in the top of the experimental cells and flowed by means of a trickle irrigation system, which divided the total flow rate into several points of water recharge. The leachate sampling device comprised a narrow channel located in the lower area of each experimental sub-cell leaching, where the leachates were sampled with the aid of a syringe. We measured the $\mathrm{pH}$, redox potential $(\mathrm{Eh} ; \mathrm{mV})$, temperature, and $\mathrm{EC}(\mu \mathrm{S} / \mathrm{cm})$ in the leachates in situ using portable devices, and corrected the values using standard solutions (HACH sensION TM378). The samples were filtered using a cellulose nitrate membrane with a pore size of $0.45 \mu \mathrm{m}$. The samples for cation analysis were later acidified to $\mathrm{pH}<2.0$ by adding ultra-pure $\mathrm{HNO}_{3}$. The samples were collected in $110 \mathrm{~mL}$ high-density polypropylene bottles, which were sealed with a double cap and stored in a refrigerator until analysis.

The cation concentrations were measured using inductively coupled plasma mass spectroscopy (ICP-MS) at ACTLABS (Ontario, Canada). The concentrations of chloride, nitrate and sulfate (in a second, untreated sample) were analyzed by ion chromatography. The alkalinity of the waters was analyzed by titration. The standard reference material NIST 1640 (ICP-MS) was used to evaluate accuracy.

To assess the potential role of organic matter in the mobility of metals, we used the Visual Minteq numerical code [39]. Visual Minteq includes a submodel for estimations of the complexation of metals with dissolved organic matter, which assumes that the composite ligand consists of a population of discrete binding sites in which the probability of occurrence of a binding site is normally distributed (Gaussian model) with respect to its log K value for proton or metal binding [40].

\section{Results and Discussion}

\subsection{Column-Leaching Experiments}

The first experiment comprised the leaching of "pure" biosolid to evaluate the possible mobility of the main anions and metals. The results showed low leaching of metals, except $\mathrm{Ni}$, possibly because of the content of this metal in the sewage sludge (Table 2). We also found a significative concentrations of As (sample SL-1) and $\mathrm{Pb}$ (sample SL-2, Table 3). The high value of EC, chloride and sulphate detected may be associated with the origin of the water (seawater) used in the treatment processes that generated the sewage sludge.

\subsection{Pilot-Scale Experiments}

The results of leaching of not-amended materials (Table 4) showed mobilization of $\mathrm{Cu}(>0.2 \mathrm{mg} / \mathrm{L}$, $\mathrm{Fe}(<1-2.0 \mathrm{mg} / \mathrm{L}), \mathrm{Mn}(0.09-0.45 \mathrm{mg} / \mathrm{L}, \mathrm{Pb}(0.02-0.08 \mathrm{mg} / \mathrm{L})$ and $\mathrm{Sb}(6-7.5 \mu \mathrm{g} / \mathrm{L})$ and other inorganic compounds (Ca, Na, Mg, and K). In addition, minor concentrations of As (4.0-7.5 $\mu \mathrm{g} / \mathrm{L}), \mathrm{Se}(<20 \mu \mathrm{g} / \mathrm{L})$ and $\mathrm{Cd}(<1.0-2.0 \mu \mathrm{g} / \mathrm{L})$ were detected. The concentrations of dissolved metals are similar to other slag 
dumps $[6,7,13]$ suggesting that the slags in the study area may mobilize significative metal amounts that can be released into the environment.

This indicates that contaminated soils and abandoned slags have high potential leachability (Tables 4 and 5). Major-element leachability may be associated with silicates and sulfides, and originated, possibly, due to the oxidation of pyrrhotite and the weathering of detected fayalite, melilite and celsian. The oxidation of pyrrhotite may mobilize $\mathrm{Fe}$ and $\mathrm{SO}_{4}$ and decrease the $\mathrm{pH}$ of the pore water:

$$
\mathrm{Fe}_{(1-\mathrm{x})} \mathrm{S}_{(\mathrm{s})}+(2-\mathrm{x} / 2) \mathrm{O}_{2}(\mathrm{~g})+\mathrm{H}_{2} \mathrm{O}=(1-\mathrm{x}) \mathrm{Fe}^{2+}+\mathrm{SO}_{4}{ }^{2-}+2 \mathrm{xH}^{+}
$$

However, the weathering of olivine (mainly fayalite) may also mobilize Fe and Mg:

$$
2 \mathrm{MeAlSiO}_{4}+2 \mathrm{H}^{+}+\mathrm{H}_{2} \mathrm{O} \rightarrow \mathrm{Me}^{\mathrm{x}+}+\mathrm{Al}_{2} \mathrm{Si}_{2} \mathrm{O}_{5}(\mathrm{OH})_{4}
$$

The high content of $\mathrm{Mn}(3.35 \%)$ and $\mathrm{ZnO}(1.34 \%)$ in olivine [9] may explain the high concentration of these elements in the leaching test. In addition, the weathering of K-feldspar detected in the slags may mobilize $\mathrm{K}$ and some metals after the dissolution of kaolinite:

$$
\mathrm{KAlSi}_{3} \mathrm{O}_{4}+2 \mathrm{H}^{+}+9 \mathrm{H}_{2} \mathrm{O} \rightarrow 2 \mathrm{~K}^{+}+\mathrm{Al}_{2} \mathrm{Si}_{2} \mathrm{O}_{5}(\mathrm{OH})_{4}+4 \mathrm{H}_{4} \mathrm{SiO}_{4}
$$

Moreover, the weathering of melilite $\left(\mathrm{Ca}_{0.7} \mathrm{Ba}_{0.4} \mathrm{Na}_{0.3} \mathrm{Sr}_{0.1} \mathrm{Zn}_{0.1} \mathrm{Fe}^{3+}{ }_{1.1} \mathrm{Al}_{0.1} \mathrm{Si}_{2} \mathrm{O}_{7}\right)$ and celsian $\left(\mathrm{BaAl}_{2} \mathrm{Si}_{2} \mathrm{O}_{8}\right)$ may also explain the mobilization of $\mathrm{Ca}, \mathrm{Na}, \mathrm{K}$ and $\mathrm{Zn}$. Besides, the presence of $\mathrm{Pb}$ may result from the presence of cotunnite and rich $\mathrm{Sb}$-galena remainders in the slags. In the cell experiment with amended materials $\mathrm{Cu}, \mathrm{Pb}$ and $\mathrm{Sb}$ were removed, however selected metals (Fe, $\mathrm{Mn}$, and $\mathrm{Ni}$ ) and metalloids (As, Se) were leached. The presence of metalloids (As, Se) in the leachates may be due to the high content of these elements in the slags (Table 2). Besides, the leaching of amended materials showed an increase of $\mathrm{Ca}, \mathrm{Mg}, \mathrm{K}$ and $\mathrm{Na}$ (Table 4) which could due to the origin of the biosolid (seawater) and the high content of these metals in the sewage sludge, which reached concentrations of $17.7 \%$ of $\mathrm{Ca}, 1.38 \%$ of $\mathrm{Na}$ and $0.74 \%$ of $\mathrm{Mg}$ (Table 2 ). In addition, organic acids and their anions may affect the weathering and dissolution rates of minerals such as feldspar and olivine [41,42]. Organic matter oxidation may therefore promote silicate weathering and kaolinite dissolution:

$$
\begin{gathered}
\mathrm{CH}_{2}+\mathrm{O}_{2} \rightarrow \mathrm{CO}_{2}+\mathrm{H}_{2} \mathrm{O} \\
\mathrm{Al}_{2} \mathrm{Si}_{2} \mathrm{O}_{5}(\mathrm{OH})_{4}+6 \mathrm{H}^{+} \rightarrow 2 \mathrm{Al}^{3+}+2 \mathrm{H}_{4} \mathrm{SiO}_{4}+\mathrm{H}_{2} \mathrm{O}
\end{gathered}
$$

Thus, leachates of contaminated soils and slags with biosolid showed a decrease in $\mathrm{pH}$ and redox potential (Table 4). Furthermore, the bicarbonate increase (Table 5) can be attributed to the reaction of silicates with $\mathrm{CO}_{2}$ and water [5] and possible carbonate buffering:

$$
\begin{gathered}
\mathrm{CaFeSiO}_{4}+\mathrm{CO}_{2}+\mathrm{H}_{2} \mathrm{O} \rightarrow \mathrm{Ca}^{2+}+\mathrm{Fe}(\mathrm{OH})_{3}+\mathrm{H}_{4} \mathrm{SiO}_{4}+\mathrm{HCO}_{3}{ }^{-} \\
\mathrm{CaCO}_{3}+\mathrm{CO}_{2}+\mathrm{H}_{2} \mathrm{O} \rightarrow \mathrm{Ca}^{2+}+2 \mathrm{HCO}_{3}{ }^{-}
\end{gathered}
$$

However, the leachability of each metal was very different in the leachates of amended materials, in which $\mathrm{As}, \mathrm{Se}, \mathrm{Ni}$ and $\mathrm{Mn}$ were mobilized, and $\mathrm{Cu}, \mathrm{Pb}$ and $\mathrm{Sb}$ were retained. Figures 2 and 3 show the retention of $\mathrm{Cu}, \mathrm{Pb}$ and $\mathrm{Sb}$ in the pilot-scale experiment, with the exception of $\mathrm{Pb}$, which mobilized at the end of the leaching experiment. Although the removal of these elements may be caused by adsorption and/or co-precipitation involving the organic matter of sewage sludge, As and Se (Figure 4) were mobilized, possibly because of the $\mathrm{pH}$-Eh conditions produced by biosolid addition. Thus, an increase in $\mathrm{pH}$ causes the anionic forms of As to be desorbed from solid phases. 
Table 4. In situ determinations and metal concentrations of leachates of pilot-scale experiments. Values in $\mu \mathrm{g} / \mathrm{L} ; \mathrm{Eh}: \mathrm{mV}$.

\begin{tabular}{|c|c|c|c|c|c|c|c|c|c|c|c|c|c|c|c|c|c|c|c|}
\hline Analyte Symbol & $\mathbf{t}(\mathrm{min})$ & $\mathrm{pH}$ & Eh & $\mathbf{C a}$ & Mg & $\mathbf{K}$ & $\mathrm{Cr}$ & Mn & $\mathbf{F e}$ & Co & $\mathbf{N i}$ & $\mathrm{Cu}$ & Zn & As & Se & Cd & $\mathbf{S b}$ & $\mathbf{B a}$ & $\mathbf{P b}$ \\
\hline Unit & & & & $\mathrm{mg} / \mathrm{L}$ & $\mathrm{mg} / \mathrm{L}$ & $\mathrm{mg} / \mathrm{L}$ & $\mu \mathrm{g} / \mathrm{L}$ & $\mu \mathrm{g} / \mathrm{L}$ & $\mu \mathrm{g} / \mathrm{L}$ & $\mu \mathrm{g} / \mathrm{L}$ & $\mu \mathrm{g} / \mathrm{L}$ & $\mu \mathrm{g} / \mathrm{L}$ & $\mu \mathrm{g} / \mathrm{L}$ & $\mu \mathrm{g} / \mathrm{L}$ & $\mu \mathrm{g} / \mathrm{L}$ & $\mu \mathrm{g} / \mathrm{L}$ & $\mu \mathrm{g} / \mathrm{L}$ & $\mu \mathrm{g} / \mathrm{L}$ & $\mu \mathrm{g} / \mathrm{L}$ \\
\hline DL & & & & 0.7 & 0.001 & 0.03 & 0.5 & 0.1 & 10 & 0.005 & 0.3 & 0.2 & 0.5 & 0.03 & 0.2 & 0.01 & 0.01 & 0.1 & 0.01 \\
\hline E-1 & 0 & 7.68 & -55 & 349 & 84.3 & 31.9 & $<50$ & 290 & $<1,000$ & 3.1 & $<30$ & 250 & $<50$ & 6 & $<20$ & 1 & 6 & 70 & 80 \\
\hline E-2 & 30 & 7.74 & -59 & 374 & 80.7 & 26.2 & $<50$ & 220 & $<1,000$ & 2.1 & $<30$ & 220 & $<50$ & 6 & $<20$ & 1 & 6 & 60 & 50 \\
\hline E-3 & 90 & 7.68 & -55 & 458 & 115 & 41.5 & $<50$ & 450 & $<1,000$ & 4.85 & 30 & 485 & $<50$ & 7.5 & $<20$ & 2 & 7.5 & 60 & 80 \\
\hline E-4 & 150 & 7.80 & -62 & 378 & 79.6 & 23.1 & 240 & 260 & 2,500 & 2.9 & $<30$ & 280 & $<50$ & 7 & $<20$ & 1 & 7 & 40 & 50 \\
\hline E-5 & 210 & 8.03 & -75 & 339 & 61.1 & 13.4 & $<50$ & 170 & $<1,000$ & 2.7 & $<30$ & 200 & $<50$ & 7 & $<20$ & 1 & 7 & 40 & 30 \\
\hline E-6 & 1,380 & 8.03 & -76 & 351 & 54.8 & 12.3 & $<50$ & 150 & $<1,000$ & 1.4 & $<30$ & 190 & $<50$ & 4 & $<20$ & $<1$ & 7 & 30 & 20 \\
\hline E-7 & 1,440 & 8.03 & -83 & 301 & 53.2 & 7.2 & $<50$ & 90 & $<1,000$ & 1.1 & $<30$ & 70 & $<50$ & 5 & $<20$ & $<1$ & 6 & 20 & 20 \\
\hline LE-1 & 0 & 7.43 & -42 & 757 & 640 & 367 & $<50$ & 450 & 2,100 & 12.9 & 100 & $<20$ & $<50$ & 34 & 100 & $<1$ & 4 & 60 & 40 \\
\hline LE-3 & 90 & 7.34 & -36 & 865 & 903 & 524 & $<50$ & 500 & 2,700 & 19.1 & 150 & $<20$ & $<50$ & 37 & 30 & 4 & 5 & 30 & 60 \\
\hline LE-4 & 150 & 7.23 & -30 & 867 & 945 & 566 & $<50$ & 500 & 2,400 & 18.9 & 160 & 20 & $<50$ & 44 & 60 & 2 & 5 & 40 & 70 \\
\hline LE-5 & 210 & 7.25 & -31 & 721 & 572 & 337 & 130 & 390 & 3,700 & 12.7 & 90 & $<20$ & $<50$ & 38 & 50 & 2 & 4 & 10 & 30 \\
\hline LE-6 & 1,380 & 7.37 & -38 & 796 & 724 & 398 & $<50$ & 450 & 5,000 & 15.8 & 120 & 40 & $<50$ & 32 & 30 & $<1$ & 5 & 110 & 130 \\
\hline LE-7 & 1,440 & 7.40 & -40 & 623 & 382 & 208 & 1760 & 460 & 14,300 & 10.7 & 80 & 70 & $<50$ & 25 & 40 & 1 & 4 & 10 & 30 \\
\hline LMW & - & 7.40 & 128 & 115 & 43.5 & 3.1 & 190 & 30 & 180 & $<0.5$ & $<30$ & $<20$ & $<50$ & $<3$ & $<20$ & $<1$ & 1 & 30 & $<1$ \\
\hline $\mathrm{C}_{\mathbf{0}}$ & - & - & - & - & - & - & 100 & - & - & - & 120 & 600 & 1,200 & 60 & 40 & 20 & 100 & 4,000 & 150 \\
\hline
\end{tabular}

LMW: low mineralized water used in the pilot-scale experiments; DL: detection limit; $\mathrm{C}_{0}$ : European limits concentrations for leachates of inert wastes (percolation assay); E-1 to E-7: leachates of contaminated soils and slags; LE-1 to LE-7: leachates of amended materials. 
Table 5. Main anions of leachates of pilot-scale experiments. DL: detection limit. Values in mg/L.

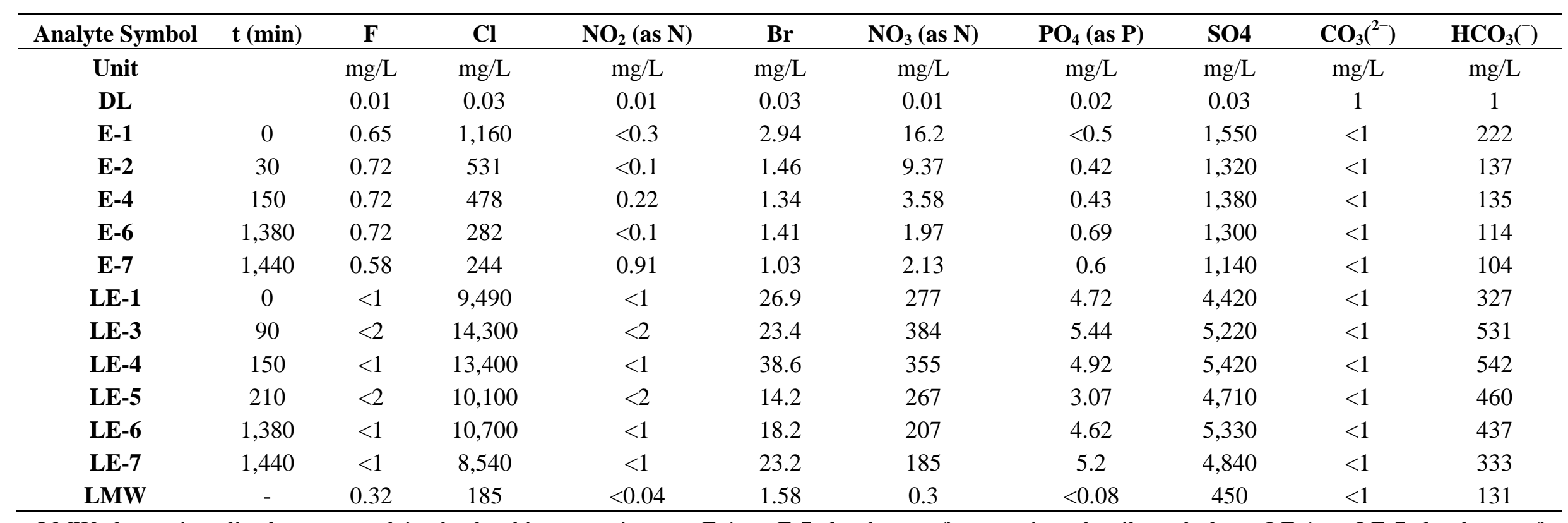

LMW: low mineralized water used in the leaching experiments; E-1 to E-7: leachates of contaminated soils and slags; LE-1 to LE-7: leachates of amended materials. 
Figure 2. Evolution of $\mathrm{Cu}$ and $\mathrm{Ba}$ in the pilot-scale experiments. Values in $\mu \mathrm{g} / \mathrm{L}$. $\mathrm{Cu} / \mathrm{Ba}-\mathrm{S}$ : change of $\mathrm{Cu}$ and $\mathrm{Ba}$ content in time, measured in effluent solution of not-amended experiment; $\mathrm{Cu} / \mathrm{Ba}-\mathrm{S}-\mathrm{SW}$ : change of $\mathrm{Cu}$ and $\mathrm{Ba}$ content in time, measured in effluent solution of amended experiment.

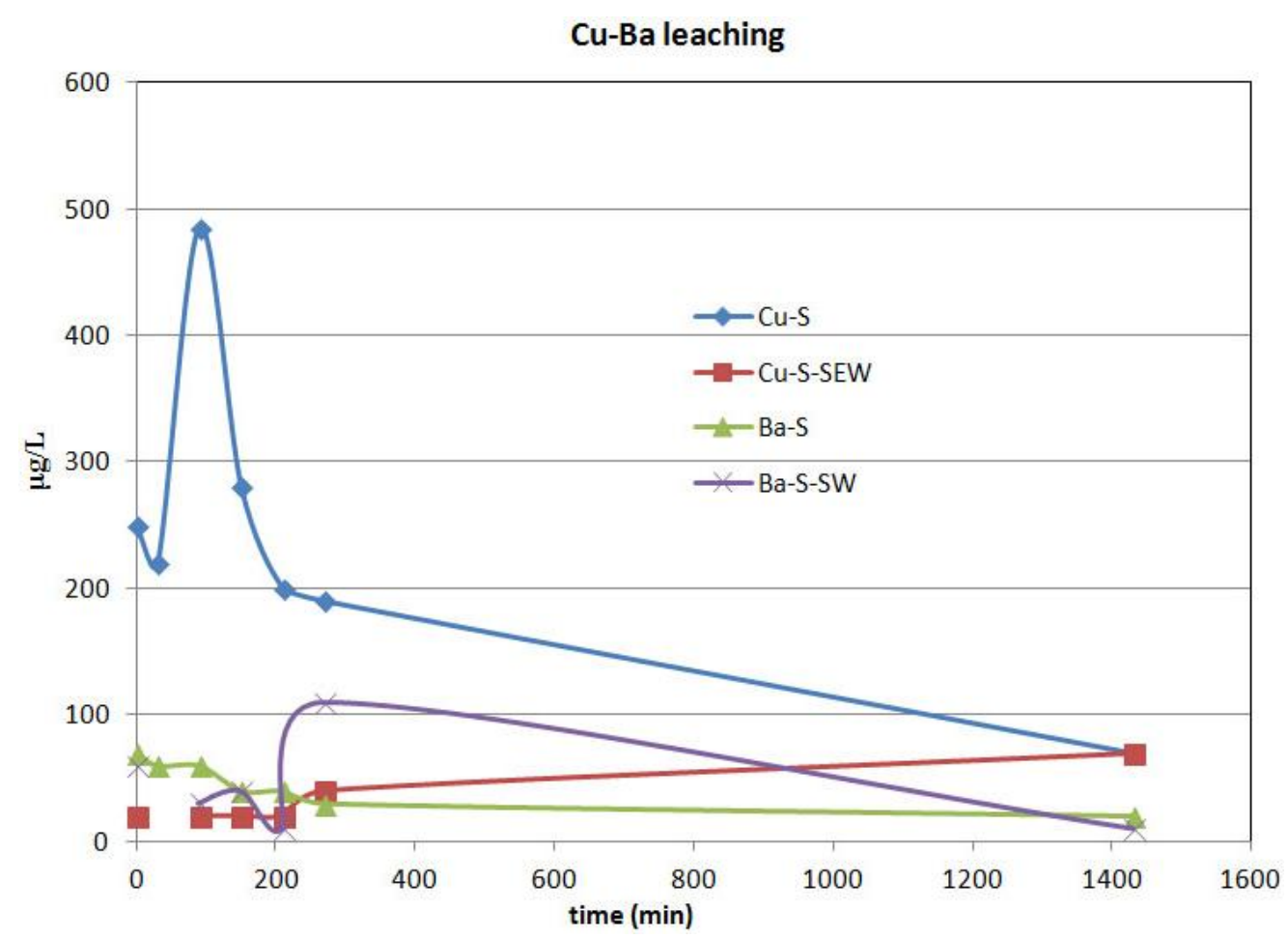

Figure 3. Evolution of $\mathrm{Pb}$ and $\mathrm{Sb}$ in the pilot-scale experiments. Values in $\mu \mathrm{g} / \mathrm{L}$. $\mathrm{Pb} / \mathrm{Sb}-\mathrm{S}$ : change of $\mathrm{Pb}$ and $\mathrm{Sb}$ content in time, measured in effluent solution of not-amended experiment; $\mathrm{Pb} / \mathrm{Sb}-\mathrm{S}-\mathrm{SW}$ : change of $\mathrm{Pb}$ and $\mathrm{Sb}$ content in time, measured in effluent solution of amended experiment.

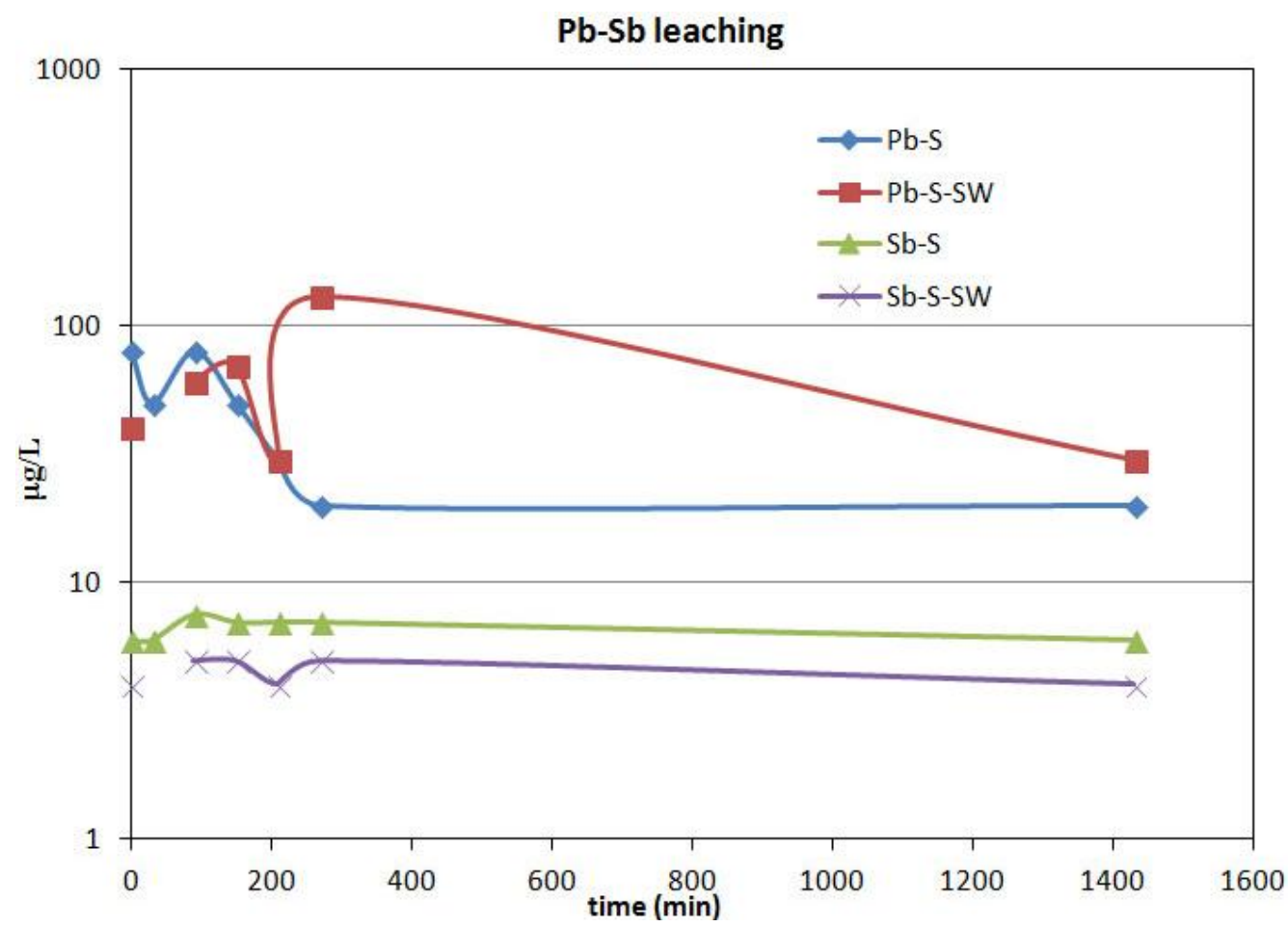


Figure 4. Evolution of As and $\mathrm{Se}$ in the pilot-scale experiments. Values in $\mu \mathrm{g} / \mathrm{L}$. As/Se-S: change of As and Se content in time, measured in effluent solution of not-amended experiment, As/Se-S-SW: change of As and Se content in time, measured in effluent solution of amended experiment.

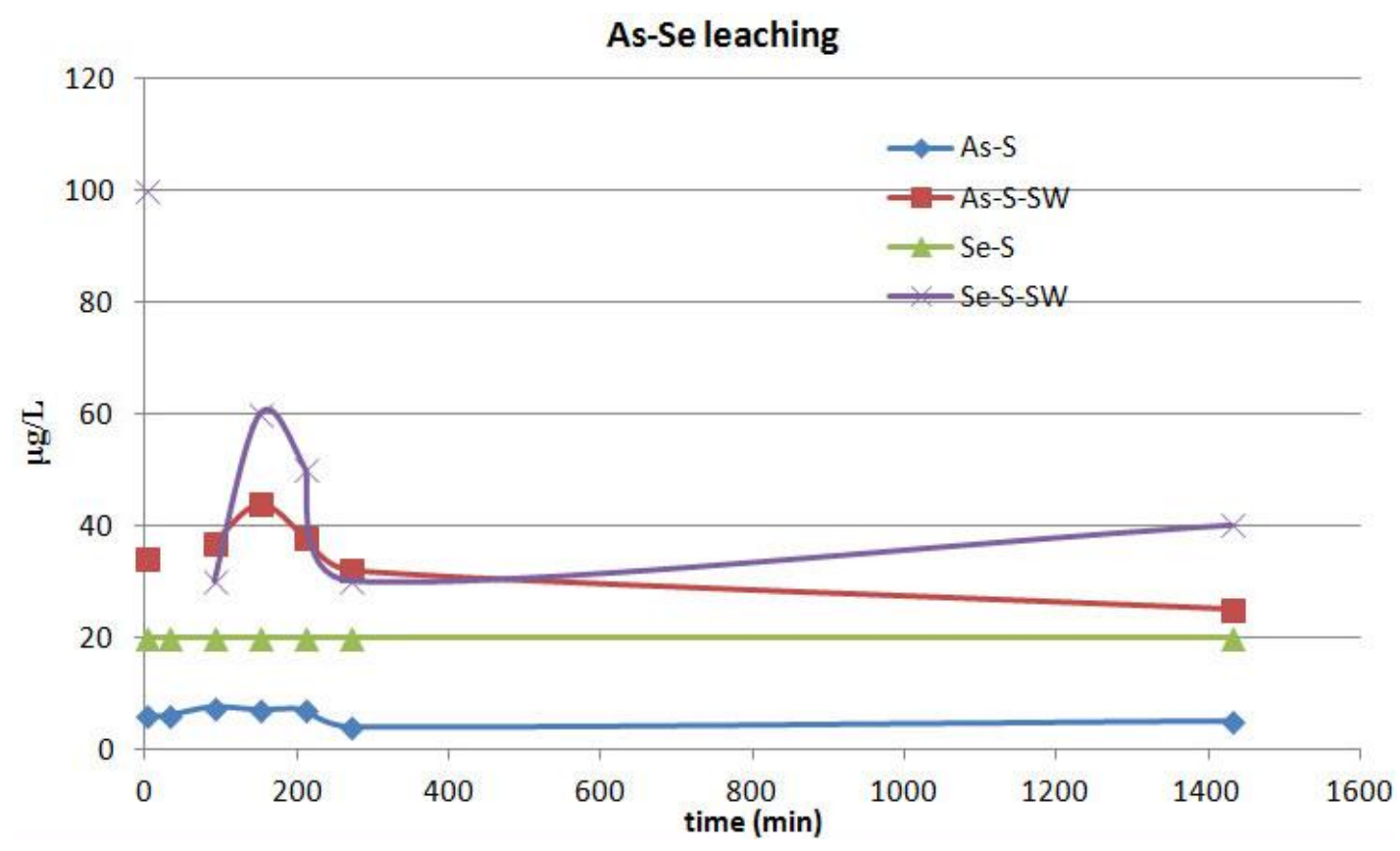

\subsection{Geochemical Modeling}

Hydrogeochemical modeling of the leachates using Minteq showed that the degree of complexation of $\mathrm{Cu}$ rose $56.3 \%$ and $57.6 \%$ in leachates with sewage sludges (Table 6), although $\mathrm{Cu}$ was immobilized by biosolids (Figure 2). Moreover, the $\mathrm{pH}$-Eh diagram from the Medusa numerical code [43] showed that $\mathrm{CuCl}_{3}{ }^{-}$was the most stable species and $\mathrm{CuCO}_{3}$ (aq) was the most stable carbonated species. Thus, the immobilization of $\mathrm{Cu}$ may be associated with possible sorption by organic matter and adsorption by oxyhydroxides of $\mathrm{Fe}$, since leachates are saturated with respect to these mineral phases (Table 7). In addition, $\mathrm{Cu}$ may be precipitated as $\mathrm{Cu}_{2} \mathrm{~S}$ at $\mathrm{pH}$ values between 6 and 8 when the Eh is low $(0.0$ to $-125 \mathrm{mV})$, which was the case in the pilot-scale experiment with amended material.

The partial retention of $\mathrm{Pb}$ coincides with the possible precipitation of chloropyromorphite. This was the most stable mineral phase in the $\mathrm{pH}$-Eh conditions of the leachates with amended material, which were saturated with respect to this mineral (Table 7). Leachates were also saturated or slightly undersaturated with respect to cerussite (Table 7). Therefore, this mineral may also control the mobility of $\mathrm{Pb}$. Likewise, $\mathrm{Pb}$ showed a high degree of complexation in sewage sludge leachates (67.6\%-70.4\%, Table 6), although this phenomenon did not seem to increase the mobility of $\mathrm{Pb}$. 
Table 6. Distribution of species in leachates of soils and slags (E-1, E-7) and leachates of amended materials (LE-1, LE-7) in the pilot-scale experiments.

\begin{tabular}{|c|c|c|c|c|}
\hline Species & E-1(\%) & E-7(\%) & LE-1(\%) & LE-7(\%) \\
\hline $\mathrm{Cu}^{+2}$ & 3.01 & 2.79 & 5.07 & 4.14 \\
\hline $\mathrm{Cu}$ DOM1 & 0.14 & 0.17 & 56.36 & 57.63 \\
\hline $\mathrm{CuOH}^{+}$ & 2.31 & 7.52 & 1.69 & 1.29 \\
\hline $\mathrm{Cu}(\mathrm{OH})_{2}(\mathrm{aq})$ & 0.16 & 1.66 & 0.05 & 0.04 \\
\hline $\mathrm{CuCl}^{+}$ & 0.07 & 0.01 & 0.70 & 0.53 \\
\hline $\mathrm{CuSO}_{4}(\mathrm{aq})$ & 1.30 & 1.33 & 2.21 & 2.22 \\
\hline $\mathrm{CuHPO}_{4}(\mathrm{aq})$ & 0.09 & 0.12 & 0.22 & 0.22 \\
\hline $\mathrm{CuCO}_{3}(\mathrm{aq})$ & 85.25 & 81.50 & 31.80 & 31.81 \\
\hline $\mathrm{CuHCO}_{3}^{+}$ & 0.52 & 0.15 & 0.40 & 0.42 \\
\hline $\mathrm{Cu}\left(\mathrm{CO}_{3}\right)_{2}{ }^{-2}$ & 7.10 & 4.62 & 1.33 & 1.59 \\
\hline $\mathrm{Pb}^{+2}$ & 4.36 & 4.36 & 3.05 & 2.53 \\
\hline Pb DOM1 & 0.42 & 0.54 & 67.68 & 70.43 \\
\hline $\mathrm{PbOH}^{+}$ & 2.65 & 9.32 & 0.81 & 0.63 \\
\hline $\mathrm{Pb}(\mathrm{OH})_{2}(\mathrm{aq})$ & 0.03 & 0.35 & - & - \\
\hline $\mathrm{PbCl}^{+}$ & 2.03 & 0.52 & 7.76 & 5.91 \\
\hline $\mathrm{PbCl}_{2}(\mathrm{aq})$ & 0.08 & - & 2.04 & 1.43 \\
\hline $\mathrm{PbSO}_{4}(\mathrm{aq})$ & 4.02 & 4.43 & 2.84 & 2.91 \\
\hline $\mathrm{Pb}\left(\mathrm{SO}_{4}\right)_{2}^{-2}$ & 0.29 & 0.23 & 0.48 & 0.58 \\
\hline $\mathrm{PbNO}_{3}^{+}$ & 0.03 & - & 0.24 & 0.13 \\
\hline $\mathrm{PbHPO}_{4}$ (aq) & 0.01 & 0.01 & 0.01 & 0.01 \\
\hline $\mathrm{Pb}\left(\mathrm{CO}_{3}\right)_{2}^{-2}$ & 5.64 & 3.96 & 0.44 & 0.53 \\
\hline $\mathrm{PbCO}_{3}(\mathrm{aq})$ & 70.89 & 73.1 & 11.01 & 11.21 \\
\hline $\mathrm{PbHCO}_{3}^{+}$ & 9.49 & 3.06 & 3.06 & 3.30 \\
\hline $\mathrm{Sb}(\mathrm{OH})_{3}$ & 99.99 & 99.97 & 99.99 & 99.99 \\
\hline $\mathrm{Mn}^{+2}$ & 60.57 & 60.63 & 65.74 & 62.12 \\
\hline $\mathrm{MnOH}^{+}$ & 0.03 & 0.13 & 0.01 & 0.01 \\
\hline $\mathrm{MnCl}_{2}(\mathrm{aq})$ & 0.02 & - & 0.98 & 0.78 \\
\hline $\mathrm{MnCl}^{+}$ & 0.77 & 0.20 & 4.60 & 3.99 \\
\hline $\mathrm{MnSO}_{4}(\mathrm{aq})$ & 20.29 & 22.37 & 22.24 & 25.89 \\
\hline $\mathrm{MnNO}_{3}^{+}$ & 0.04 & - & 0.56 & 0.35 \\
\hline $\mathrm{MnHPO}_{4}(\mathrm{aq})$ & 0.37 & 0.54 & 0.59 & 0.67 \\
\hline $\mathrm{MnHCO}_{3}^{+}$ & 3.30 & 1.06 & 1.65 & 2.02 \\
\hline $\mathrm{MnCO} 3(\mathrm{aq})$ & 14.56 & 15.03 & 3.50 & 4.06 \\
\hline $\mathrm{Ni}^{+2}$ & 52.51 & 57.99 & 52.68 & 47.47 \\
\hline Ni DOM1 & 0.06 & 0.09 & 14.69 & 16.59 \\
\hline $\mathrm{NiOH}^{+}$ & 0.16 & 0.62 & 0.07 & 0.05 \\
\hline $\mathrm{NiCl}^{+}$ & 0.25 & 0.07 & 1.37 & 1.13 \\
\hline $\mathrm{NiSO}_{4}(\mathrm{aq})$ & 19.74 & 24.00 & 20.00 & 20.20 \\
\hline $\mathrm{NiNO}^{3+}$ & 0.06 & 0.01 & 0.71 & 0.43 \\
\hline $\mathrm{NiHPO}_{4}(\mathrm{aq})$ & 0.11 & 0.17 & 0.16 & 0.17 \\
\hline $\mathrm{NiCO}_{3}(\mathrm{aq})$ & 9.36 & 10.6 & 2.08 & 2.3 \\
\hline $\mathrm{NiHCO}_{3}^{+}$ & 17.71 & 6.29 & 8.17 & 9.58 \\
\hline
\end{tabular}


Table 7. Calculated saturation index for selected leachates of pilot-scale experiments. Saturation indices calculated using MINTEQ.

\begin{tabular}{llll}
\hline Phase Mineral & Leachate E-1 & Leachate E-7 & Leachate LE-1 \\
\hline Fe oxy-hydroxides & & & \\
$\mathrm{Fe}(\mathrm{OH})_{3}$ & 5.874 & 6.281 & 5.621 \\
$\mathrm{Goethite}$ & 8.073 & 8.48 & 8.12 \\
$\mathrm{Fe}(\mathrm{OH})_{2.7} \mathrm{Cl}_{0.3}$ & 8.822 & 8.889 & 9.098 \\
Sulfates & & & \\
Jarosite & 5.805 & 4.869 & 8.055 \\
Jarosite-Na & 1.73 & 0.701 & 3.836 \\
Gypsum & -0.346 & -0.371 & -0.042 \\
Pb minerals & & & \\
Cerrusite & 0.115 & -0.477 & -0.965 \\
Chloropyromorphite & 12.217 & 10.647 & 10.307 \\
Cu minerals & & & \\
Cu(OH $)_{2}$ & -2.253 & -0.792 & -2.773 \\
Azurite & -2.036 & 0.272 & -3.547 \\
\hline
\end{tabular}

The retention of $\mathrm{Sb}$ may be associated with possible precipitation of $\mathrm{Sb}_{2} \mathrm{O}_{3}$, which was the most stable mineral phase in the experimental conditions (Figure 5). The mobility of metalloids such as As and $\mathrm{Se}$ is favored by the $\mathrm{pH}$-Eh conditions of leachates, since under elevated $\mathrm{pH}$ the anionic forms of As may be desorbed from solid phases and As becomes relatively mobile under reducing conditions. Thus, in the leaching of lead metallurgical slags in high-molecular-weight organic solutions, metals and As are released in large amounts during the early stage of the experiments [5]. In addition, organic acids from biosolids may reductively dissolve the Fe oxyhydroxides associated with weathered slags and mobilize $\mathrm{Fe}, \mathrm{Ni}, \mathrm{Cu}, \mathrm{Cr}$ and $\mathrm{Co}$ by reductive dissolution, as shown in similar situations [25].

In the $\mathrm{pH}$-Eh conditions of the column experiments, the most stable $\mathrm{Ni}$ species is $\mathrm{NiCl}_{2}$ under oxidizing conditions. The precipitation of $\mathrm{NiO}_{2}$ is only possible under oxidizing conditions at high $\mathrm{pH}$ values (>8.5). At a low redox potential, a high $\mathrm{pH}$ could cause precipitation of the sulfide NiS. Thus, $\mathrm{Ni}$ mobilization in the experiments may be caused by the presence of significant amounts of leachable $\mathrm{Ni}$ in the sewage sludge $(39 \mathrm{mg} / \mathrm{kg})$ and the high $\mathrm{Cl}^{-}$content, although the complexation of $\mathrm{Ni}$ with dissolved organic matter is significant (Table 6). In addition, similar experiments suggested the migration of $\mathrm{Ni}$ as organic complexes [29].

The mobility of $\mathrm{Mn}$ is probably derived from the dissolution of olivine, which may contain up to $3.35 \%$ of $\mathrm{MnO}$ [9]. The dominant aqueous species in leachates are $\mathrm{Mn}^{2+}(60 \%-65.7 \%)$ and $\mathrm{MnSO}_{4}$ (20.2\%-25.8\%, Table 6), which coincides with the $\mathrm{pH}$-Eh diagram. 
Figure 5. Eh-pH diagram for the system Sb-SO $\mathrm{SO}_{4}-\mathrm{H}_{2} \mathrm{O}$. Built by MEDUSA code (Puigdomènech 2004). (c): solid phase; $E_{\mathrm{SHE} / \mathrm{v}}$ Eh (volts); $\left[\mathrm{Cl}^{-}\right]_{\mathrm{TOT}}=32.72 \mathrm{M}$; $\left[\mathrm{Sb}(\mathrm{OH})_{3}\right]_{\mathrm{TOT}}=10.00 \mathrm{mM} ;\left[\mathrm{SO}_{4}{ }^{2-}\right]_{\text {тот }}=16.14 \mathrm{M} ; \mathrm{T}=25^{\circ} \mathrm{C}$.

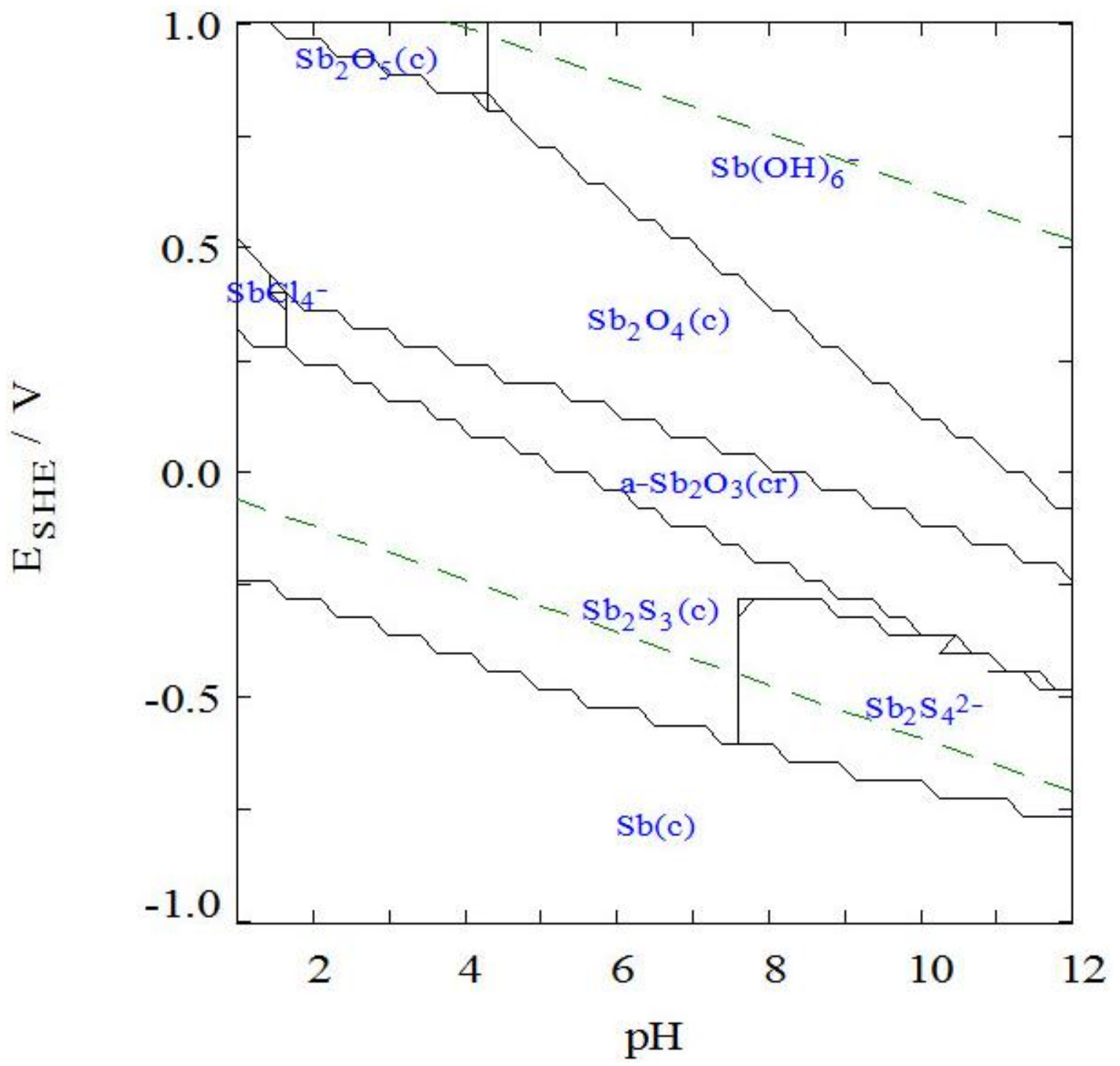

\section{Conclusions}

The leaching experiments with organic amendments on contaminated soils and smelter slags showed that $\mathrm{As}, \mathrm{Se}, \mathrm{Ni}$ and $\mathrm{Mn}$ were mobilized, whilst $\mathrm{Cu}, \mathrm{Pb}$ and $\mathrm{Sb}$ were retained. The removed metals: $\mathrm{Cu}, \mathrm{Pb}$ and $\mathrm{Sb}$, decreased their concentrations from $250 \mu \mathrm{g} / \mathrm{L}, 80 \mu \mathrm{g} / \mathrm{L}$ and $6 \mu \mathrm{g} / \mathrm{L}$, respectively in the leachates of contaminated materials, to $<20 \mu \mathrm{g} / \mathrm{L}, 40 \mu \mathrm{g} / \mathrm{L}$ and $4 \mu \mathrm{g} / \mathrm{L}$, respectively, in the amended material. The immobilization of $\mathrm{Cu}$ by sewage sludge may be associated with possible sorption by organic matter and adsorption by oxyhydroxides of $\mathrm{Fe}$, as leachates are saturated with respect to these mineral phases. In addition, $\mathrm{Cu}$ may be precipitated as $\mathrm{Cu}_{2} \mathrm{~S}$ at $\mathrm{pH}$ values between 6 and 8 when the Eh is low $(0.0$ to $-125 \mathrm{mV})$, which is the case in the slag/sewage sludge experiment. Although lead mobility is favored by high dissolved organic carbon concentrations, the possible precipitation of chloropyromorphite may control the mobility of $\mathrm{Pb}$ in the leaching experiments. As and Se were leached in the sewage sludge experiment, which indicates that high $\mathrm{pH}$ and reducing 
conditions may mobilize these metalloids. The leaching experiments indicated that the formation of organo-Ni complexes in sludge-amended slags might be an important factor in Ni leaching. The organic amendments used in this study increased some metal and metalloid concentrations in the leachates (As, $\mathrm{Se}, \mathrm{Fe}, \mathrm{Mn}$ and $\mathrm{Ni}$ ). This suggests that the amendments could promote groundwater and seawater contamination in the Sierra Almagrera coastal region, if they are used to remediate slag-contaminated areas. However, organic amendments did not increase $\mathrm{Cu}, \mathrm{Pb}$ and $\mathrm{Sb}$ concentrations. Hence, they may be used as reactive material in contaminated areas, if these metals are the priority contaminants of smelting sites. Furthermore, the high salinity associated with sewage sludges may favor metal mobility due to the increase in ionic strength and the possible cation exchange associated with the high $\mathrm{Na}$ and $\mathrm{K}$ content of sewage sludges.

\section{Acknowledgements}

This study was supported by a financial agreement between the Universitat Politècnica de Catalunya (UPC) and the private sector (project C-7613).

\section{References}

1. Dybowska, A.; Farago, M.; Valsami-Jones, E.; Thornton, I. Remediation strategies for historical mining and smelting sites. Sci. Prog. 2006, 89, 71-138.

2. Ettler, V.; Legendre, O.; Bodénan, F.; Touray, J.C. Primary phases and natural weathering of old lead-zinc pyrometallurgical slag from Pribram, Czech Republic. Can. Mineral. 2001, 39, 873-888.

3. Ettler, V.; Piantone, P.; Touray, J.C. Mineralogical control on inorganic contaminant mobility in leachate from lead-zinc metallurgical slag: experimental approach and long-term assessment. Min. Magaz. 2003, 67, 1269-1283.

4. Ettler, V.; Komárková, M.; Jehlicka, J.; Coufal, P.; Hradil, D.; Machovic, V.; Delorme, F. Leaching of lead metallurgical slag in citric solutions-implications for disposal and weathering in soil environments. Chemosphere 2004, 57, 567-577.

5. Ettler, V.; Jehlicka, J.; Masek, V.; Hruska, J. The leaching behaviour of lead metallurgical slag in high-molecular-weight (HMW) organic solutions. Min. Magaz. 2005, 69, 737-747.

6. Ettler, V.; Johan, Z.; Kríbek, B.; Sebek, O.; Mihaljevic, M. Mineralogy and environmental stability of slags from the Tsumeb smelter, Namibia. Appl. Geochem. 2009, 24, 1-15.

7. Piatak, N.M.; Seal, R.R., II; Hammarstrom, J.M. Mineralogical and geochemical controls on the release of trace elements from slags produced by base-and precious-metal smelting at abandoned mine sites. Appl. Geochem. 2004, 19, 1039-1064.

8. Costagliola, P.; Benvenuti, M.; Chiarantini, L.; Bianchi, S.; Di Benedetto, F.; Paolieri, M.; Rossato, L. Impact of ancient metal smelting on arsenic pollution in the pecora River Valley, Southern Tuscany, Italy. Appl. Geochem. 2008, 23, 1241-1259.

9. Navarro, A.; Cardellach, E.; Mendoza, J.L.; Corbella, M.; Domènech, L.M. Metal mobilization from base-metal smelting slag dumps in Sierra Almagrera (Almería, Spain). Appl. Geochem. 2008, 23, 895-913.

10. Seignez, N.; Gauthier, A.; Bulteel, D.; Damidot, D.; Potdevin, J.L. Leaching of lead metallurgical slags and pollutant mobility far from equilibrium conditions. Appl. Geochem. 2008, 23, 3699-3711. 
11. Pareuil, P.; Bordas, F.; Joussein, E.; Bollinger, J.C. Alteration of a Mn-rich slag in contact with soil: In-situ experiment during one year. Environ. Pollut. 2010, 158, 1311-1318.

12. Piatak, N.M.; Seal, R.R., II. Mineralogy and the release of trace elements from slag from the Hegeler Zinc smelter, Illinois (USA). Appl. Geochem. 2010, 25, 302-320.

13. Parsons, M.B.; Bird, D.K.; Einaudi, M.T.; Alpers, C.N. Geochemical and mineralogical controls on trace elements release from the Penn Mine base-metal slag dump, California. Appl. Geochem. 2001, 16, 1567-1593.

14. Ludwig, R.D.; McGregor, R.G.; Blowes, D.W.; Benner, S.G.; Mountjoy, K. A permeable reactive barrier for treatment of heavy metals. Ground Water 2002, 40, 59-66.

15. Navarro, A.; Martínez, F. Effects of sewage sludge application on heavy metal leaching from mine tailings impoundments. Biores. Technol. 2008, 99, 7521-7530.

16. Schwab, P.; Zhu, D.; Banks, M.K. Heavy metal leaching from mine tailings as affected by organic amendments. Biores. Technol. 2007, 98, 2935-2941.

17. Hulshof, A.H.M.; Blowes, D.W.; Gould, W.D. Evaluation of in situ layers for treatment of acid mine drainage: A field comparison. Water Res. 2006, 40, 1816-1826.

18. Jordán, M.M.; García-Sánchez, E.; Almendro-Candel, M.B.; Navarro-Pedreño, J.; Gómez-Lucas, I.; Meléndez, I. Geological and environmental implications in the reclamation of limestone quarries in Sierra de Callosa (Alicante, Spain). Environ. Earth Sci. 2009, 59, 687-694.

19. García Navarro, F.J.; Amorós Ortiz-Villajos, J.A.; Sánchez Jiménez, C.J.; Bravo Martín-Consuegra, S.; Márquez Cubero, E.; Jiménez Ballesta, R. Application of sugar foam to red soils in a semiarid Mediterranean environment. Environ. Earth Sci. 2009, 59, 603-611.

20. Basta, N.T.; Gradwohl, R.; Snethen, K.L.; Schroder, J.L. Chemical inmobilization of Lead, Zinc and Cadmium in smelter-contaminated soils using biosolids and rock phosphate. J. Environ. Qual. 2001, 30, 1222-1230.

21. Theodoratus, P.; Moirou, A.; Xenidis, A.; Paspialanis, I. The use of sewage sludge for the stabilization of soil contaminated by mining activities. J. Hazard. Mat. 2000, 77, 177-191.

22. Simon, L. Stabilization of metals in acidic mine spoil with amendments and red fescue (Festuca rubra L.) growth. Environ. Geochem. Health 2005, 27, 289-300.

23. Pichtel, J.R.; Jick, W.A.; Sutton, P. Comparison of amendments and management practises for long-term reclamation of abandoned mine lands. J. Environ. Qual. 1994, 23, 766-772.

24. Forsberg, L.S.; Ledin, S. Effects of sewage sludge on $\mathrm{pH}$ and plant availability of metals in oxiding sulphide mine tailings. Sci. Total Environ. 2006, 353, 21-35.

25. Ribet, I.; Ptacek, C.J.; Blowes, D.W.; Jambor, J.L. The potential for metal release by reductive dissolution of weathered mine tailings. J. Cont. Hydrol. 1995, 17, 239-273.

26. Cravotta, C.A. Effect of sewage sludge on formation of acidic ground water at a reclaimed coal mine. Ground Water 1998, 35, 9-19.

27. Edenborn, H.M. Use of poly(lactic acid) amendments to promote the bacterial fixation of metals in zinc smelter tailings. Biores. Technol. 2004, 92, 111-119.

28. Chiu, K.K.; Ye, Z.H.; Wong, M.H. Growth of Vetiveria zizanoides and Phragmities australis on $\mathrm{Pb} / \mathrm{Zn}$ and Cumine tailings amended with manure compost and sewage sludge: A greenhouse study. Biores. Technol. 2006, 97, 158-170. 
29. Ashworth, D.J.; Alloway, B.J. Soil mobility of sewage sludge-derived dissolved organic matter, copper, nickel and zinc. Environ. Pollut. 2004, 127, 137-144.

30. Urasa, I.T.; Macha, S.F. Investigation into heavy metal uptake by waste water sludges. Water Air Soil Poll. 1997, 109, 207-218.

31. Park, J.H.; Lamb, D.; Paneerselvam, P.; Choppala, G.; Bolan, N.; Chung, J.W. Role of organic amendments on enhanced bioremediation of heavy metal(loid) contaminated soils. J. Hazard. Mater. 2011, 185, 549-574.

32. Amos, R.T.; Mayer, K.U.; Blowes, D.W.; Ptacek, C.J. Reactive transport modeling of column experiments for the remediation of acid mine drainage. Environ. Sci. Technol. 2004, 38, 3131-3138.

33. Navarro, A.; Collado, D.; Carbonell, M.; Sánchez, J.A. Impact of mining activities in a semi-arid environment: Sierra Almagrera district, SE Spain. Environ. Geochem. Health 2004, 26, 383-393.

34. Navarro, A.; Biester, H.; Mendoza, J.L.; Cardellach, E. Mercury speciation and mobilization in contaminated soils of the valle del azogue $\mathrm{Hg}$ mine (SE, Spain). Environ. Geol. 2006, 49, 1089-1101.

35. Navarro, A.; Cardellach, E. Mobilization of Ag, Heavy metals and Eu from the waste deposit of Las Herrerías mine (Almería, SE Spain). Environ. Geol. 2009, 56, 1389-1404.

36. Moreno, D.; Aguilera, P.A.; Castro, H. Assessment of the conservation status of seagrass (Posidonia Oceanica) meadows: Implications for monitoring strategy and the decision-making process. Biol. Conserv. 2001, 102, 325-332.

37. O'Kelly, C. Mechanical properties of dewatered sewage sludge. Waste Manag. 2005, 25, 47-52.

38. Navarro, A.; Chimenos, J.M.; Muntaner, D.; Fernández, I. Permeable reactive barriers for the removal of heavy metals: Lab-scale experiments with low-grade magnesium oxide. Ground Water Monitor. Remed. 2006, 26, 142-152.

39. Allison, J.D.; Brown, D.S.; Novo-Gradac, K.J. MINTEQA2/PRODEFA2, A Geochemical Assessment Model for Environmental Systems: Version 3.0 Users Manual; U.S. Environmental Protection Agency: Athens, GA, Greece, 1991.

40. Christensen, J.B.; Botma, J.J.; Christensen, T.H. Complexation of $\mathrm{Cu}$ and $\mathrm{Pb}$ by DOC in polluted groundwater: A comparison of experimental data and predictions by computer speciation models (WHAM and MINTEQA2). Water Res. 1999, 33, 3231-3238.

41. Drever, J.I.; Stillings, L.L. The role of organic acids in mineral weathering. Colloids Surf. 1997, 120, 167-181.

42. Olsen, A.A.; Rimstidt, J.D. Oxalate-promoted forsterite dissolution at low pH. Geochem. Cosmoch. Acta 2008, 72, 1758-1766.

43. Puigdomenech, I. Make Equilibrium using Sophisticated Algoritms (MEDUSA) Program. Inorganic Chemistry Department Website. Available online: http://www.kemi.kth.se/medusa/ (accessed on 26 November 2012).

(C) 2012 by the authors; licensee MDPI, Basel, Switzerland. This article is an open access article distributed under the terms and conditions of the Creative Commons Attribution license (http://creativecommons.org/licenses/by/3.0/). 